he was little more than 20 years old. Twenty years later he was made membre de l'Institut and professor at the Collège de France, where he proved himself to be the foremost authority in the world on Semitic epigraphy. He possessed in the highest degree the specially French gifts of brilliant insight and exact reasoning, and these gave a distinction to all the varied work of his long career.

He was much broken by the death of his mother in 1916, at the age of 101, but he still maintained much of his old verve. Only last summer at the centenary of the Société Asiatique he seemed as vigorous as ever-full of interest in all that was being done and planning work for the future. His end must have come unexpectedly. In answer to a letter urging him to come to the centenary celebration of this Society, he wrote that he was not very well and spoke of des ennuis et des soucis. Within a week he died at the age of 75 , and he died young.

A. Cowley.

\title{
Dr. G. Buchanan Gray
}

By the death of Dr. G. Buchanan Gray, England loses one of its most distinguished Hebraists and Biblical scholars, and Oxford a valued member of its teaching staff. Dr. Gray's death took place on 2nd November, 1922, at a meeting of the Theological Board, not many minutes before he was to have delivered his address as President for the year to the Oxford Society of Historical Theology; the circumstances were, therefore, tragic, as he was in his 57 th year and appeared to be in good health.

He studied the Semitic languages at Oxford and Marburg, where he attended the courses of J. Wellhausen, and entered the Independent ministry in 1893 ; two years before he had been appointed tutor at Mansfield College, Oxford, where he was promoted to be Professor of Hebrew and Old Testament Exegesis in 1900, and he further held certain University appointments connected with these studies. His Studies in

JRAS. APRIL 1923. 
Hebrew Proper Names (1896) received very favourable notice, and brought him into the front rank of Hebraists. He contributed the commentary on Numbers to the "Temple Bible", and a more extensive treatise on the same book to the "International Critical Commentary"; to this latter series he also furnished a commentary on the first portion of Isaiah, and the completion of the very elaborate work on Job which the late Professor Driver had left unfinished at his death. These works embody the latest results of research and are characterized by painstaking thoroughness. Dr. Gray was greatly interested in Palestinian archæology, and contributed to the Quarterly Statement of the Palestine Exploration Fund, which he helped to administer. He also devoted some attention to that elusive subject, the Forms of Hebrew Poetry, on which he published a monograph.

In the Preface to his $J o b$, Dr. Gray acknowledged his obligations to Dr. Driver, whose influence in giving new directions to the study of his subject and founding a school with many distinguished representatives must have been as great as that exercised by any teacher of a literary subject. One who comes from the perusal of Dr. Pusey's Minor Prophets to the study of the commentaries composed by or under the influence of his successor finds himself in a new environment. The new school is justly commended for the attention which it devotes to archæology and in general for the sobriety of its conclusions.

D. S. M.

\section{The Rev. John Drew Bate}

The Rev. John Drew Bate was born in Plymouth in the year 1836, and by his death at a ripe old age the Society has lost one of its oldest and most valued members. He was sent to India by the Baptist Missionary Society in 1886, and, after a short stay in Eastern Bengal, was posted to Allahabad, where, earning the respect and affection of all classes of the com- 